\title{
Anaerobaculum mobile sp. nov., a novel anaerobic, moderately thermophilic, peptide- fermenting bacterium that uses crotonate as an electron acceptor, and emended description of the genus Anaerobaculum
}

Cátedra de Microbiología,

Facultad de Química y

Facultad de Ciencias,

Universidad de la República, CC 1157, Montevideo, Uruguay

\author{
Rodolfo Javier Menes and Lucía Muxí \\ Author for correspondence: Rodolfo Javier Menes. Tel: +5982 9244209. Fax: +59829241906. \\ e-mail: jmenes@bilbo.edu.uy
}

\begin{abstract}
A novel anaerobic, moderately thermophilic, peptide-fermenting bacterium, strain NGA', was isolated from an anaerobic wool-scouring wastewater treatment lagoon. The cells were Gram-negative, straight rods of 0.5-1.0 $\times$ 2.0-4.0 $\mu \mathrm{m}$, motile by means of a single flagellum. The DNA G+C content was $51.5 \mathrm{~mol} \%$. The optimum pH and temperature range for growth were 6.6-7.3 and 55-60 ${ }^{\circ} \mathrm{C}$, respectively. The optimum $\mathrm{NaCl}$ concentration was $0.08 \mathrm{~g} \mathrm{I}^{-1}$. The bacterium fermented organic acids (malate, tartrate, pyruvate, glycerol and fumarate), a few carbohydrates (starch, glucose, fructose and gluconate), Casamino acids, tryptone and yeast extract. Carbohydrates and organic acids were converted to acetate, hydrogen and $\mathrm{CO}_{2}$. The bacterium oxidized leucine to isovalerate with crotonate as an electron acceptor, but not in co-culture with Methanothermobacter thermoautotrophicus DSM $3720^{\top}$. Thiosulfate, sulfur and cystine were reduced to sulfide and crotonate was reduced to butyrate with glucose and tryptone-yeast extract as electron donors. Phylogenetic analysis of the 16S rRNA gene indicated that strain NGAT was related to Anaerobaculum thermoterrenum (98\% similarity ), the only described species of the genus. The DNA-DNA hybridization value for strain NGA $^{\top}$ and $A$. thermoterrenum ACM $5076^{\top}$ was $40.8 \%$. On the basis of these results, strain NGA ${ }^{\top}$ is proposed as a novel species of the genus Anaerobaculum, namely Anaerobaculum mobile sp. nov. The type strain is NGA $^{\top}$ ( = DSM 13181' $=$ ATCC BAA-54' ${ }^{\mathrm{T}}$ ).
\end{abstract}

Keywords: anaerobic degradation, crotonate, electron acceptor, thermophile, Anaerobaculum mobile sp. nov.

\section{INTRODUCTION}

Anaerobic biological treatment is a frequently applied technology for decontamination of agroindustrial wastewaters by conversion of organic compounds to methane and carbon dioxide. The application of this treatment under thermophilic conditions has increased in recent years. However, when proteins are a major constituent of such wastes, their degradation is often incomplete (McInerney, 1988; Hansen et al., 1998)

The EMBL accession number for the 16S rDNA sequence of strain NGA ${ }^{\top}$ is AJ243189. and the same situation arises when lipid-rich wastes are treated (Angelidaki et al., 1990). Isolation and physiological characterization of novel strains will help to explain their role in carbon flow in those anaerobic ecosystems.

In anoxic environments, the oxidation of certain amino acids such as alanine, valine, leucine and isoleucine, proceeds in association with hydrogen-scavenging organisms, due to the unfavourable $\Delta G^{\circ}$ of the initial deamination step, which leads to the corresponding keto acid (Stams, 1994). However, acetate (Örlygsson et al., 1996), thiosulfate (Fardeau et al., 1997; Faudon et al., 1995; Mechichi et al., 2000) and crotonate (Girbal et al., 1997) have also been reported to act as 
electron acceptors for amino acid utilization in anaerobiosis.

In this report, a novel thermophilic, peptide-fermenting bacterium within the genus Anaerobaculum, strain $\mathrm{NGA}^{\mathrm{T}}$, is described. Moreover, evidence of the use of crotonate as an electron acceptor by both Anaerobaculum thermoterrenum (Rees et al., 1997), the only currently described species within the genus, and strain $\mathrm{NGA}^{\mathrm{T}}$ is presented.

\section{METHODS}

Strains. Methanothermobacter thermoautotrophicus DSM $3720^{\mathrm{T}}$ was obtained from Deutsche Sammlung von Mikroorganismen and Zellkulturen, Braunschweig, Germany (DSMZ) and $A$. thermoterrenum ACM 5076 ${ }^{\mathrm{T}}$ was from the Australian Collection of Microorganisms, Brisbane, Australia.

Media and culture conditions. Enrichment and cultivation were performed in $\mathrm{BC}$ medium supplemented with yeast extract $\left(0.2 \mathrm{~g} \mathrm{l}^{-1} ;\right.$ Difco). The basal medium (BC) contained $\left(1^{-1}\right): 0.3 \mathrm{~g} \mathrm{KH}_{2} \mathrm{PO}_{4}, 0.6 \mathrm{~g} \mathrm{NaCl}, 0.1 \mathrm{~g} \mathrm{MgCl}_{2} .6 \mathrm{H}_{2} \mathrm{O}, 0.08 \mathrm{~g}$ $\mathrm{CaCl}_{2} .2 \mathrm{H}_{2} \mathrm{O}, 2 \mathrm{mg}$ resazurin, $1.0 \mathrm{~g} \mathrm{NH}_{4} \mathrm{Cl}, 3.6 \mathrm{~g} \mathrm{KHCO}_{3}$, $11.92 \mathrm{~g}$ HEPES and $10 \mathrm{ml}$ trace element solution (Touzel \& Albagnac, 1983). Media were prepared anaerobically under $\mathrm{O}_{2}$-free $\mathrm{N}_{2}$, the gas phase was replaced with $\mathrm{N}_{2} / \mathrm{CO}_{2}(70: 30$, $\mathrm{v} / \mathrm{v}$ ), adjusted to $\mathrm{pH} 7 \cdot 0$ and autoclaved for $15 \mathrm{~min}$ at $121^{\circ} \mathrm{C}$. Prior to inoculation, $1 \mathrm{ml}$ vitamin solution (Touzel \& Albagnac, 1983), $20 \mathrm{ml}$ filter-sterilized sulfidecysteine solution $\left[1 \cdot 25 \%(\mathrm{w} / \mathrm{v}) \mathrm{Na}_{2} \mathrm{~S} .9 \mathrm{H}_{2} \mathrm{O}, 1 \cdot 25 \%(\mathrm{w} / \mathrm{v})\right.$ cysteine. $\mathrm{HCl}]$ and the substrate were added.

Physiological characterization. Substrate studies were performed in duplicate in Hungate tubes with $5 \mathrm{ml}$ medium (or in $125 \mathrm{ml}$ vials with $20 \mathrm{ml}$ medium). Substrates were added from anaerobic filter-sterilized stock solutions. Insoluble substrates were added to each tube or vial before media were dispensed. Soluble substrates were tested at concentrations of $5-10 \mathrm{mM}$ and insoluble substrates at $2-5 \mathrm{~g} \mathrm{l}^{-1}$. The test was considered positive for substrate utilization when an increase in OD was detected and confirmed by substrate end product quantification. For insoluble substrates, the test was considered positive when an increase in end product formation was detected with respect to controls tubes with no added substrate. To study substrate degradation in coculture with a methanogen, $M$. thermoautotrophicus DSM $3720^{\mathrm{T}}$ was pre-grown in $\mathrm{BC}$ under $140 \mathrm{kPa} \mathrm{H} \mathrm{H}_{2} / \mathrm{CO}_{2}(80: 20$, $\mathrm{v} / \mathrm{v}$ ). After growth, the gas phase was replaced with $\mathrm{N}_{2} / \mathrm{CO}_{2}$ $(70: 30, \mathrm{v} / \mathrm{v})$, substrate was added from stock solutions and vials were inoculated with strain $\mathrm{NGA}^{\mathrm{T}}$. Electron acceptor utilization, $\mathrm{pH}$, temperature and $\mathrm{NaCl}$ growth range determinations were carried out in triplicate in Hungate tubes containing $10 \mathrm{ml}$ modified PY broth - a basal medium containing peptone $\left(5 \mathrm{~g} \mathrm{l}^{-1}\right.$; Difco), tryptone $\left(5 \mathrm{~g} \mathrm{l}^{-1}\right.$; Difco) and yeast extract (10 g 1 ${ }^{-1}$; Difco) (Smibert \& Krieg, 1994), without sodium bicarbonate and prepared under an $\mathrm{N}_{2}$ atmosphere. For electron acceptor utilization (at a final concentration of $10 \mathrm{mM}$, except for sulfite which was $2 \mathrm{mM}$ ), PY was reduced with $1.25 \%(\mathrm{w} / \mathrm{v})$ cysteine. $\mathrm{HCl}$ solution (20 $\mathrm{ml}$ per 1 medium). For $\mathrm{pH}$ experiments, the following buffers were added from stock solutions to a final concentration of $20 \mathrm{mM}$ : acetate buffer for $\mathrm{pH} 4.0$ and $4 \cdot 8$; phosphate buffer for $\mathrm{pH} 5 \cdot 8,6 \cdot 2,6 \cdot 8,7 \cdot 2$ and $7 \cdot 8$; and Tris buffer for $\mathrm{pH} 8.0$ and 8.8 (Smibert \& Krieg, 1994). Solid media were prepared by the addition of agar $(2 \%, w / v)$. All incubations were performed at $55^{\circ} \mathrm{C}$ unless stated otherwise.
All liquid media were inoculated $(1 \%)$ with late exponential phase cultures in PY broth.

Enrichment and isolation. Sludge samples from an anaerobic wool-scouring wastewater treatment lagoon in Trinidad (Uruguay) were enriched for anaerobic, thermophilic, oleate-degrading bacteria. A crotonate-degrading enrichment was then obtained from the oleate-degrading consortium in BCYT (basal BC medium with tryptone and yeast extract, each at $0.5 \mathrm{~g} \mathrm{l}^{-1}$ ), supplemented with crotonate (15 mM; Sigma) as previously described (Menes et al., 2001).

After three subcultures, a stable enrichment culture was obtained which did not produce methane. This crotonate enrichment was used to inoculate tubes of BCYT agar supplemented with crotonate $(15 \mathrm{mM})$ and incubated for 1 month. Culture purification was achieved by the agar-shakedilution tube process. Purity was checked by phase-contrast microscopy (Axioplan; Zeiss).

Analytical techniques. Fermentation products were measured in centrifuged $(6000 \mathrm{~g}, 10 \mathrm{~min})$ samples of the culture media. Values were corrected by subtracting the amount produced in control cultures without substrate. Volatile fatty acids and crotonate were measured by GC or HPLC. The GC (SRI) was equipped with a column packed with $10 \%$ SP-1000/1\% $\mathrm{H}_{3} \mathrm{PO}_{4}$ on $100 / 120$ Chromosorb W AW (Supelco) connected to an FID. $\mathrm{N}_{2}$ was the carrier gas at a flow rate of $24 \mathrm{ml} \mathrm{min} \mathrm{m}^{-1}$ and the oven temperature was $150{ }^{\circ} \mathrm{C}$. The HPLC (Waters) was equipped with an organic acid column (Chrompack) connected to UV and refractive index detectors (Waters, Millipore). The mobile phase was $0.005 \mathrm{M} \mathrm{H}_{2} \mathrm{SO}_{4}$ at a flow rate of $0.8 \mathrm{ml} \mathrm{min}^{-1}$ and the column temperature was $35^{\circ} \mathrm{C}$. Sulfide was quantified by the methylene blue method (Rand et al., 1975). Methane and hydrogen were quantified using a GC (SRI) equipped with a thermal conductivity detector and a molecular sieve $13 \mathrm{X}$ (80-100 mesh; Chrompack) packed column. Argon was used as the carrier gas at a flow rate of $20 \mathrm{ml} \mathrm{min}^{-1}$. The detector temperature was $100{ }^{\circ} \mathrm{C}$ and the column temperature was $35^{\circ} \mathrm{C}$. Growth was measured at $660 \mathrm{~nm}$ by inserting Hungate tubes into the holder of a Genesys 5 (Spectronic; Milton Roy) spectrophotometer.

Electron microscopy. For electron microscopic studies, the culture was centrifuged at $3000 \mathrm{~g}$ for $6 \mathrm{~min}$ at $4{ }^{\circ} \mathrm{C}$, the supernatant was discarded and the pellet was fixed in $2.5 \%$ glutaraldehyde and $2 \%$ paraformaldehyde in $0 \cdot 1 \mathrm{M}$ phosphate buffer ( $\mathrm{pH} 7 \cdot 4)$ for $2 \mathrm{~h}$. Samples were then post-fixed in $1.0 \%$ osmium tetroxide, dehydrated in an ascending gradient of ethanol $(50,70,80,90$ and $95 \%)$ and then impregnated in propylene oxide. Finally, they were embedded in Poly/ Bed 812 resin (Polysciences 18976-2590). Ultrathin sections were cut with an ultratome Super Nova (Reichter-Jung), stained with uranyl acetate and lead citrate, and observed under a JEM-1200 EX II (JEOL). The negative staining photomicrographs were taken at the DSMZ.

DNA extraction and phylogenetic analysis. Samples $(10 \mathrm{ml})$ from cells grown in PY were concentrated by centrifugation $(6000 \mathrm{~g}, 15 \mathrm{~min})$, washed with $\mathrm{NaCl}$ solution $\left(0.9 \mathrm{~g} \mathrm{l}^{-1}\right.$ in water) and resuspended in $500 \mu \mathrm{l}$ lysozyme solution $(10 \mathrm{mg}$ $\mathrm{ml}^{-1}$ in $120 \mathrm{mM}$ sodium phosphate buffer, $\mathrm{pH} \mathrm{8.0)}$. After incubation for $15 \mathrm{~min}$ at $37^{\circ} \mathrm{C}$, SDS was added (final concentration of $1 \%, \mathrm{w} / \mathrm{v}$ ) and three cycles of freezing at $-70^{\circ} \mathrm{C}$ for $1 \mathrm{~h}$ and thawing at $37^{\circ} \mathrm{C}$ for $45 \mathrm{~min}$ were applied to complete the lysis. Protein extraction and nucleic acid precipitation were performed according to Van Elsas \& Smalla (1995). Amplification and 16S rDNA sequence 
analysis were performed as reported by Fernández et al. (1999), except for the sequence data alignment, which was achieved using the CLUSTAL w package (Thompson et al., 1994) and corrected by manual inspection. Sequencing of the purified PCR product was done at the University of Florida DNA Sequencing Core Laboratory, using ABI Prism Big Dye Terminator cycle sequencing protocols developed by Applied Biosystems (Perkin-Elmer). The fluorescently labelled extension products were analysed on an Applied Biosystems model 373 Stretch DNA sequencer or 377 DNA Sequencer (Perkin-Elmer). Oligo primers were designed using OLIGO 4.0 (National BioSciences) and synthesized by Gemini Biotech. Nucleotide sequences were aligned and assembled using programs in the SEQUENCER 3.0 software package (GeneCodes).

The new sequence was compared with other released sequences in the GenBank database using the BLAST program (Altschul et al., 1997). The phylogenetic tree was constructed by the neighbour-joining method (Saitou \& Nei, 1987) with the PHYLIP 3.5c package using the Kimura distance model (Felsenstein, 1993). Bootstrap resampling analysis for 100 replicates was performed to estimate the confidence of the tree topology. Only unambiguously aligned positions were used for phylogenetic analysis (1229 positions, positions 101-1413 by Escherichia coli numbering).

DNA base composition and DNA-DNA hybridization. The $\mathrm{G}+\mathrm{C}$ content of the DNA was determined at the DSMZ by HPLC as described by Mesbah et al. (1989). Non-methylated $\lambda$ DNA (Sigma) was used as the standard. Hybridization of strain $\mathrm{NGA}^{\mathrm{T}}$ and $A$. thermoterrenum ACM $5076^{\mathrm{T}}$ was carried out at the DSMZ.

\section{RESULTS AND DISCUSSION}

\section{Morphological and physiological characteristics}

In a previous work, a stable thermophilic, crotonatedegrading enrichment was obtained for the isolation of long-chain fatty acid-degrading bacteria (Menes et al.,

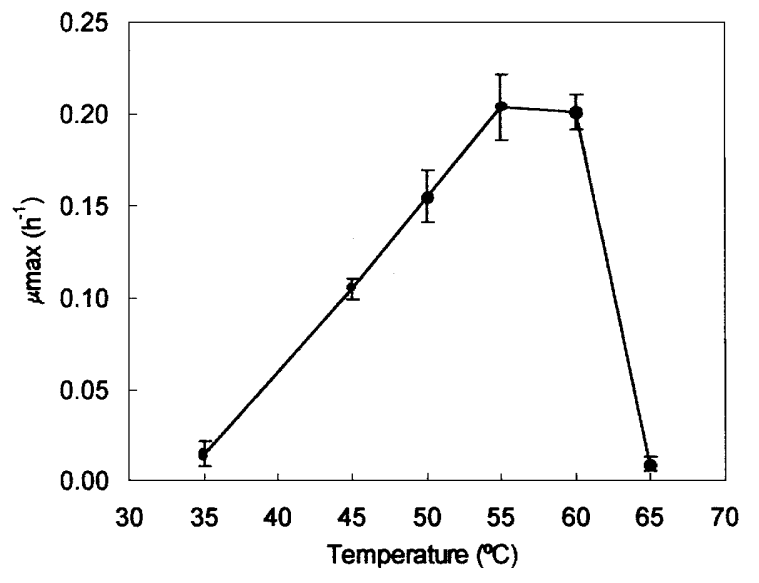

Fig. 2. Growth rate of strain $N G A^{\top}$ as a function of temperature. $\mu_{\text {max }}$, Maximum growth rate. The experiment was performed in triplicate in PY broth. Bars, SD of three datasets for each temperature.

2001). A $10^{-7}$ dilution of this crotonate enrichment was used to inoculate tubes of BCYT agar supplemented with crotonate and, after 1 week incubation, two types of colonies developed. Small colonies $(0.5 \mathrm{~mm})$ were light brown and consisted of non-motile rods that did not degrade crotonate. Large colonies $(1.0-1.5 \mathrm{~mm})$ were white, lens shaped, with entire margins and consisted of large $(0.5 \times 2 \cdot 0-4.0 \mu \mathrm{m})$ motile rods. Five of these colonies were purified in BCYT-crotonate agar and a representative culture, designated $\mathrm{NGA}^{\mathrm{T}}$, was selected for further characterization. Cells of $\mathrm{NGA}^{\mathrm{T}}$ were variable in size with longer cells $(4-8 \mu \mathrm{m})$ being observed in older cultures. They stained Gram-negative and ultrathin sections

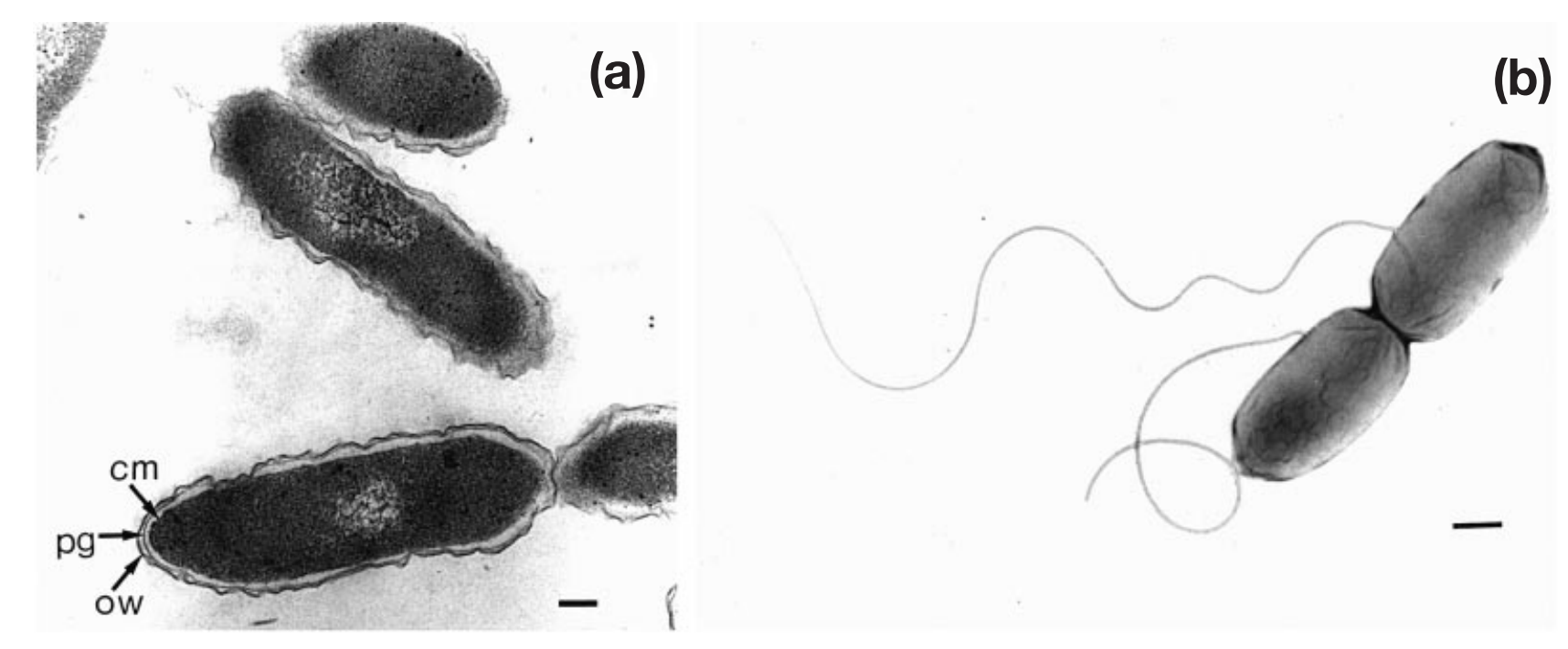

Fig. 1. Transmission electron micrographs of cells of strain $N_{G A}{ }^{\top}$. (a) Ultrathin section showing typical Gram-negative cell wall structure (bar, $0.2 \mu \mathrm{m}$; ow, outer cell wall; pg, peptidoglycan layer; $\mathrm{cm}$, cytoplasmic membrane). (b) Negatively stained preparation showing a dividing cell with single laterally inserted flagella (bar, $0.5 \mu \mathrm{m}$ ). 
Table 1. Substrates degraded by strain $\mathrm{NGA}^{\top}$ in pure culture and in co-culture with $M$. thermoautotrophicus DSM $3720^{\top}$

Carbon balances were calculated assuming the production of $2 \mathrm{~mol} \mathrm{CO}_{2}$ per mol glucose, tartrate and malate, and 1 mol $\mathrm{CO}_{2}$ per mol pyruvate and glycerol degraded. Experiments were performed in BC medium supplemented with yeast extract $\left(0 \cdot 2 \mathrm{~g} 1^{-1}\right)$ and incubated for $30 \mathrm{~d}$ at $55^{\circ} \mathrm{C}$, except for fumarate $(90 \mathrm{~d})$. The concentration of fermentation products was corrected by subtracting the values obtained in control vials without substrate. No degradation was observed in uninoculated controls. ND, Not detected.

\begin{tabular}{|c|c|c|c|c|c|c|}
\hline \multirow[t]{2}{*}{ Substrate } & \multirow{2}{*}{$\begin{array}{c}\text { Substrate } \\
\text { consumed } \\
(\mathbf{m M})\end{array}$} & \multicolumn{3}{|c|}{ Fermentation products $\left(\mathrm{mmol} \mathrm{I}^{-1}\right)$ : } & \multirow{2}{*}{$\begin{array}{c}\text { Electron } \\
\text { balance }(\%)\end{array}$} & \multirow{2}{*}{$\begin{array}{c}\text { Carbon } \\
\text { balance }(\%)\end{array}$} \\
\hline & & Acetate & Hydrogen & Methane & & \\
\hline \multicolumn{7}{|l|}{ In pure culture: } \\
\hline Glucose $(8.5 \mathrm{mM}), \mathrm{R}=1.8^{*}$ & $1 \cdot 6$ & $3 \cdot 5$ & $6 \cdot 7$ & & 108 & 109 \\
\hline Glucose $(8.5 \mathrm{mM}), \mathrm{R}=27^{*}$ & $7 \cdot 5$ & $15 \cdot 1$ & $29 \cdot 8$ & & 100 & 100 \\
\hline Pyruvate $(10 \mathrm{mM})$ & $4 \cdot 3$ & $3 \cdot 5$ & $4 \cdot 1$ & & 84 & 81 \\
\hline Glycerol (11.4 mM) & $3 \cdot 0$ & $3 \cdot 1$ & $6 \cdot 4$ & & 90 & 103 \\
\hline Tartrate $(4 \cdot 2 \mathrm{mM})$ & $4 \cdot 2$ & $3 \cdot 9$ & $3 \cdot 8$ & & 92 & 93 \\
\hline Malate $(9 \cdot 0 \mathrm{mM})$ & $2 \cdot 1$ & $1 \cdot 8$ & $4 \cdot 6$ & & 94 & 86 \\
\hline \multicolumn{7}{|l|}{ In co-culture: } \\
\hline Glucose $(8.5 \mathrm{mM})$ & $8 \cdot 5$ & $16 \cdot 9$ & ND & $8 \cdot 5$ & 100 & 100 \\
\hline Fumarate $(6.0 \mathrm{mM})$ & $4 \cdot 3$ & $5 \cdot 0$ & ND & $2 \cdot 4$ & 112 & 113 \\
\hline Malate $(9 \cdot 0 \mathrm{mM})$ & $9 \cdot 0$ & $8 \cdot 6$ & ND & $4 \cdot 6$ & 98 & 96 \\
\hline
\end{tabular}

* R, Ratio of headspace volume to culture medium volume.

revealed a typical Gram-negative cell wall structure (Fig. 1a). They were motile and a single flagellum, inserted in the lateral region of the cell body, was observed in negatively stained electron micrographs (Fig. 1b). During the exponential growth phase, most of the cells grew in pairs. Spores or sheath formation were never observed under our culture conditions. Strain $\mathrm{NGA}^{\mathrm{T}}$ was a strict anaerobe, as shown by its inability to grow in PY under aerobic conditions. Growth occurred at $\mathrm{NaCl}$ concentrations of up to $15 \mathrm{~g} \mathrm{l}^{-1}$, with an optimum in PY broth with no added $\mathrm{NaCl}\left(0.08 \mathrm{~g} \mathrm{l}^{-1}\right)$. The optimum temperature for growth was $55-60^{\circ} \mathrm{C}$; no growth was observed above $65^{\circ} \mathrm{C}$ (Fig. 2). The optimum $\mathrm{pH}$ for growth was 6.6-7.3 and growth occurred between $\mathrm{pH} 5 \cdot 8$ and 8.8. Strain $\mathrm{NGA}^{\mathrm{T}}$ fermented glucose, organic acids (pyruvate, tartrate and malate) and glycerol to acetate, hydrogen and, presumably, $\mathrm{CO}_{2}$ (Table 1). Glucose and malate degradation were enhanced in co-culture with $M$. thermoautotrophicus. Furthermore, the absence of reduction products other than hydrogen and the enhancement of glucose utilization by an increase in the headspace to medium volume ratio (Table 1), suggest hydrogen inhibition of glucose utilization. Fumarate fermentation was not observed in pure culture or in co-culture with $M$. thermoautotrophicus in $30 \mathrm{~d}$. However, after $90 \mathrm{~d}$ incubation, a very slow fermentation was detected by acetate and methane production (Table 1). The bacterium did not ferment crotonate, but could reduce it to butyrate in the presence of yeast extract and tryptone, glucose, Casamino acids and leucine (Table 2). The observed stoichiometric oxidation of leucine to isovalerate coupled to crotonate reduction to butyrate (Table 2) indicates that crotonate was used as electron acceptor, as has been reported for Clostridium acetireducens. However, the latter was also capable of fermenting it in the absence of electron donors (Girbal et al., 1997). To our knowledge, this is the first reported bacterium that uses crotonate exclusively as an electron acceptor. Strain $\mathrm{NGA}^{\mathrm{T}}$, like C. acetireducens (Girbal et al., 1997), could not perform leucine oxidation by interspecies hydrogen transfer. Crotonate, sulfur, cystine and thiosulfate addition also enhanced growth from tryptone and yeast extract (PY medium), Casamino acids and glucose, as indicated by an increase in OD and by production of reduction compounds (butyrate and sulfide, respectively) (Table 2). The ability to reduce thiosulfate, sulfur and cystine may represent a means of eliminating inhibition by hydrogen, as has been suggested for thiosulfate reduction by Thermoanaerobacter spp. (Faudon et al., 1995), members of the Thermotogales (Jeanthon et al., 1995), Coprothermobacter platensis (Etchebehere \& Muxí, 2000) and A. thermoterrenum (Rees et al., 1997).

Fumarate, acetate, sulfate, sulfite and nitrate were not used as electron acceptors in PY broth. Other substrates tested but not utilized by strain $\mathrm{NGA}^{\mathrm{T}}$ were: sorbitol, melibiose, adonitol, cellobiose, arabinose, dextrin, polygalacturonate, xylan and inulin. Crotonate, butyrate, oleate and benzoate were not utilized in co-culture with $M$. thermoautotrophicus DSM $3720^{\mathrm{T}}$. 
Table 2. Electron acceptors used by strain $\mathrm{NGA}^{\top}$ and crotonate reduction by $A$. thermoterrenum strain $A C M 5076^{\top}$

Experiments were performed in $10 \mathrm{ml} \mathrm{PY}$ broth or BC medium supplemented with yeast extract $\left(0 \cdot 2 \mathrm{~g}{ }^{-1}\right)$ in $15 \mathrm{ml}$ tubes and incubated for $30 \mathrm{~d}$ at $55^{\circ} \mathrm{C}$. The concentration of fermentation products in $\mathrm{BC}$ was corrected by subtracting the values obtained in control tubes supplemented with electron acceptor but without substrate. ND, Not detected.

\begin{tabular}{|c|c|c|c|c|c|}
\hline \multirow[t]{2}{*}{ Medium } & \multirow{2}{*}{$\begin{array}{c}\text { Crotonate } \\
\text { consumed } \\
(\mathrm{mM})\end{array}$} & \multirow[t]{2}{*}{$\mathrm{OD}_{660}$} & \multicolumn{3}{|c|}{ Products $(\mathrm{mM})$ : } \\
\hline & & & Acetate & Butyrate & Sulfide \\
\hline \multicolumn{6}{|l|}{ Strain $\mathbf{N G A}^{\mathrm{T}}$} \\
\hline \multicolumn{6}{|l|}{ PY medium } \\
\hline No acceptor & & $0 \cdot 149$ & $17 \cdot 0$ & $\mathrm{ND}$ & $1 \cdot 0$ \\
\hline Crotonate $(26 \mathrm{mM})$ & $26 \cdot 0$ & 0.577 & $22 \cdot 0$ & $26 \cdot 9$ & $1 \cdot 1$ \\
\hline Thiosulfate $(20 \mathrm{mM})$ & & $0 \cdot 853$ & - & - & $16 \cdot 0$ \\
\hline Sulfur $\left(4 \mathrm{~g}^{-1}\right)$ & & $0 \cdot 401$ & - & - & $9 \cdot 8$ \\
\hline Cystine $\left(2 \mathrm{~g} \mathrm{l}^{-1}\right)$ & & $0 \cdot 515$ & - & - & $13 \cdot 0$ \\
\hline \multicolumn{6}{|l|}{$\mathrm{BC}+$ glucose $(8.5 \mathrm{mM})$} \\
\hline No acceptor & & $0 \cdot 051$ & $1 \cdot 8$ & ND & $0 \cdot 7$ \\
\hline Crotonate $(23 \mathrm{mM})$ & $6 \cdot 8$ & $0 \cdot 149$ & $4 \cdot 6$ & $6 \cdot 2$ & - \\
\hline Thiosulfate (20 mM) & & $0 \cdot 096$ & $3 \cdot 6$ & ND & $2 \cdot 5$ \\
\hline \multicolumn{6}{|c|}{$\mathrm{BC}+$ Casamino acids $\left(1 \mathrm{~g} \mathrm{l}^{-1}\right)$} \\
\hline No acceptor & & $0 \cdot 040$ & $0 \cdot 8$ & ND & - \\
\hline Crotonate $(13 \mathrm{mM})$ & 5.9 & $0 \cdot 113$ & $2 \cdot 2$ & $5 \cdot 4$ & - \\
\hline \multicolumn{6}{|l|}{$\mathrm{BC}+$ leucine* $(6 \mathrm{mM})$} \\
\hline No acceptor & & $0 \cdot 020$ & $0 \cdot 3$ & $\mathrm{ND}$ & - \\
\hline Crotonate $(26 \mathrm{mM})$ & $13 \cdot 5$ & $0 \cdot 128$ & $0 \cdot 3$ & $12 \cdot 8$ & - \\
\hline \multicolumn{6}{|l|}{ Strain ACM 5076 } \\
\hline \multicolumn{6}{|l|}{ PY medium } \\
\hline No acceptor & & $0 \cdot 060$ & $14 \cdot 5$ & ND & $0 \cdot 5$ \\
\hline Crotonate $(25 \mathrm{mM})$ & $5 \cdot 7$ & $0 \cdot 070$ & 17.6 & 3.9 & - \\
\hline Thiosulfate (20 mM) & & $0 \cdot 610$ & ND & ND & $14 \cdot 0$ \\
\hline Sulfur $\left(4 \mathrm{~g} \mathrm{l}^{-1}\right)$ & & $0 \cdot 167$ & $\mathrm{ND}$ & $\mathrm{ND}$ & $10 \cdot 0$ \\
\hline
\end{tabular}

* Only isovalerate $(5 \cdot 6 \mathrm{mM})$ was detected in the culture with crotonate.

\section{Phylogenetic analysis}

The 16S rDNA sequence (1367 bp) of strain $\mathrm{NGA}^{\mathrm{T}}$ corresponded to positions $32-1413$ of the $16 \mathrm{~S}$ rDNA of E. coli. This sequence was compared with all sequences currently available in the GenBank database. Phylogenetic analysis (Fig. 3) revealed that the closest relatives of strain $\mathrm{NGA}^{\mathrm{T}}$ were $A$. thermoterrenum (Rees et al., 1997), with a sequence similarity of $98.0 \%$, and Aminobacterium colombiense (Baena et al., 1998), with a sequence similarity of $84 \cdot 4 \%$. Clearly, strain $\mathrm{NGA}^{\mathrm{T}}$ clustered with $A$. thermoterrenum, a result supported by the high bootstrap value ( $100 \%$ of 100 replicates). Due to the high level of similarity $(98.0 \%)$ with the only described species of the genus Anaerobaculum, DNA-DNA hybridization was performed and a value of $40.8 \%$ was obtained. At present, the phylogenetic definition of a species generally includes strains with $70 \%$ or greater DNA-DNA relatedness (Wayne et al., 1987). From the value of $40.8 \%$ obtained, it is therefore concluded that strain $\mathrm{NGA}^{\mathrm{T}}$ belongs to a new species within the genus Anaerobaculum. Furthermore, the difference in DNA
$\mathrm{G}+\mathrm{C}$ content between strain $\mathrm{NGA}^{\mathrm{T}}(51.5 \mathrm{~mol} \%)$ and A. thermoterrenum (44 mol\%; Rees et al., 1997) is larger than $3 \%$, the maximum range generally accepted for members of a well-defined species (Stackebrandt \& Liesack, 1993).

Several phenotypic properties support this conclusion. Both strains are able to utilize tryptone, Casamino acids, yeast extract, starch, malate, tartrate, pyruvate, glycerol, glucose and fructose, and unable to grow on lactose, xylose, cellulose, CM-cellulose, gelatin, maltose, sucrose, galactose, rhamnose, raffinose, Gum Arabic, malonate, lactate or succinate. They share the ability to reduce thiosulfate, sulfur and cystine with tryptone and yeast extract as electron donors and, as shown in Table 2, A. thermoterrenum ACM 5076 ${ }^{\mathrm{T}}$ is also able to reduce crotonate to butyrate in PY medium supplemented with crotonate. However, the extent and rate of crotonate reduction and the increase in OD are lower than those observed for strain $\mathrm{NGA}^{\mathrm{T}}$. Experiments performed with different amounts of crotonate always showed that $\mathrm{NGA}^{\mathrm{T}}$ was a more efficient crotonate reducer than ACM 5076 ${ }^{\mathrm{T}}$, even using media 


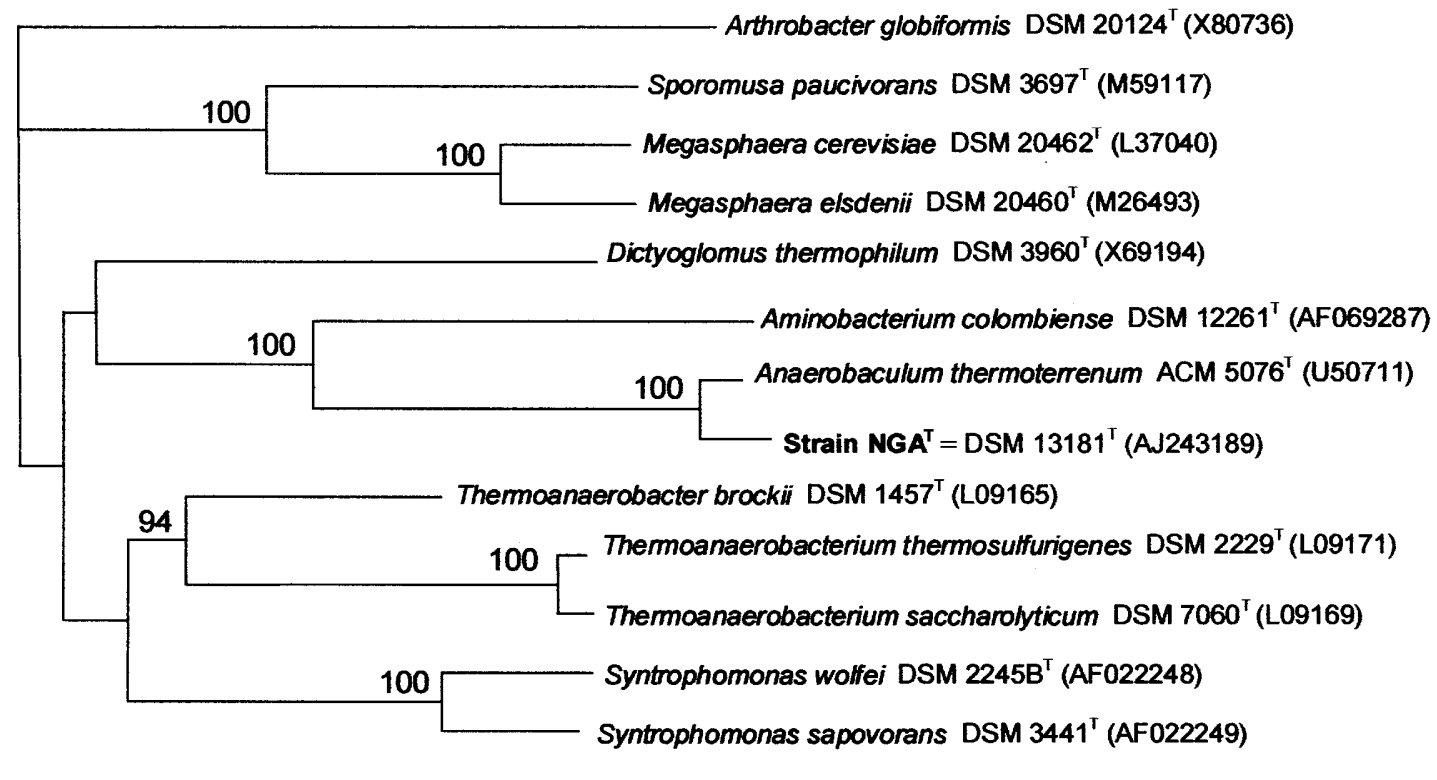

0.1

Fig. 3. Phylogenetic tree derived from the analysis of the $16 \mathrm{~S}$ rDNA sequences of strain $\mathrm{NGA}^{\top}$ and other related species. Bar, 10 nt substitutions per $100 \mathrm{nt}$. Bootstrap values of 100 resamplings are shown for the closest relatives.

Table 3. Phenotypic differential characteristics of strain NGA ${ }^{\top}$ and $A$. thermoterrenum ACM $5076^{\top}$

\begin{tabular}{|lcc|}
\hline Characteristic & Strain NGA $^{\mathbf{T}}$ & A. $_{\text {thermoterrenum }}$ \\
\hline Size $(\mu \mathrm{m})$ & $0 \cdot 5-1 \cdot 0 \times 2 \cdot 0-4 \cdot 0$ & $0 \cdot 75 \times 2 \cdot 00$ \\
Morphology & Straight rods & Straight or slightly curved rods \\
Motility & + & - \\
Flagellum & + & - \\
Optimum NaCl concn for growth $\left(\mathrm{g}^{-1}\right)$ & $0 \cdot 0$ & 10 \\
DNA G+C content (mol\%) & $51 \cdot 5$ & 44 \\
Sheath formation & - & + \\
Utilization of: & - & + \\
Fumarate & - & + \\
Citrate & - & + \\
2-Oxoglutarate & - & + \\
Glutamate & - & + \\
Mannose & - & + \\
Pectin & + & $\mathrm{NR}$ \\
Gluconate & & \\
\hline
\end{tabular}

NR, Not reported.

* Data from Rees et al. (1997).

supplemented with $\mathrm{NaCl}\left(10 \mathrm{~g}^{-1}\right)$ for the latter (data not shown).

Strain $\mathrm{NGA}^{\mathrm{T}}$ differs from $A$. thermoterrenum in its motility (presence of a single flagellum), its inability to ferment citrate, 2-oxoglutarate, glutamate, mannose and pectin, and in optimum $\mathrm{NaCl}$ concentration (Table 3). Citrate fermentation was reported as a distinctive trait for A. thermoterrenum (Rees et al., 1997), but this ability could not be shown for strain $\mathrm{NGA}^{\mathrm{T}}$ even using different culture media: $\mathrm{BC}$ medium, Brackish bicarbonate-buffered, sulfide-reduced medium (Rees et al., 1997) or in co-culture with $M$. thermoautotrophicus after $90 \mathrm{~d}$ incubation. The habitats from which both organisms were isolated were also different: A. thermoterrenum was isolated 
from the production water of a petroleum reservoir, with high salinity, which may explain its high optimum $\mathrm{NaCl}$ concentration (Rees et al., 1997), whereas $\mathrm{NGA}^{\mathrm{T}}$ was enriched and isolated from an anaerobic lagoon treating wool-scouring effluent.

The phenotypic characteristics and the results of $16 \mathrm{~S}$ rDNA sequence analysis, DNA $\mathrm{G}+\mathrm{C}$ content and DNA-DNA hybridization confirm that strain $\mathrm{NGA}^{\mathrm{T}}$ represents a novel species within the genus Anaerobaculum, for which the name Anaerobaculum mobile sp. nov. is proposed.

\section{Emended description of the genus Anaerobaculum (Rees et al. 1997)}

Chemo-organotrophic anaerobe. Moderately thermophilic. Straight to slightly curved rods. Motile by means of a single flagellum or non-motile. In complex media, some strains grow with a sheath-like material extending past the cell poles. No spores observed. Gram-negative. Ferments organic acids and a limited number of carbohydrates to acetate, hydrogen and $\mathrm{CO}_{2}$. Peptone and yeast extract also fermented. Utilizes a range of electron acceptors: thiosulfate, sulfur and cystine are reduced to sulfide and crotonate is reduced to butyrate. The DNA $\mathrm{G}+\mathrm{C}$ content is $44.0-51.5 \mathrm{~mol} \%$. The type species is Anaerobaculum thermoterrenum.

\section{Description of Anaerobaculum mobile sp. nov.}

Anaerobaculum mobile (mo'bi.le. L. masc. adj. mobile motile).

Straight rods, $0 \cdot 5-1 \cdot 0 \times 2 \cdot 0-4 \cdot 0 \mu \mathrm{m}$, motile by means of a single flagellum inserted in the lateral region of the cell body, occur singly or in pairs. Gram-negative. Strictly anaerobic and chemo-organotrophic. No spores observed. Moderately thermophilic. Growth occurs at $35-65^{\circ} \mathrm{C}$, with an optimum between 55 and $60{ }^{\circ} \mathrm{C}$, and at pH 5.4-8.7, with an optimum between 6.6 and 7.3. The optimum $\mathrm{NaCl}$ concentration is $0.08 \mathrm{~g}^{-1}$ (in media with no added $\mathrm{NaCl}$ ), but growth occurs up to $15 \mathrm{~g} \mathrm{NaCl}^{-1}$. Ferments malate, tartrate, pyruvate, glycerol, starch, glucose, fructose, gluconate, Casamino acids, tryptone and yeast extract. Carbohydrates and organic acids are converted to acetate, hydrogen and $\mathrm{CO}_{2}$. Oxidizes leucine to isovalerate with crotonate as electron acceptor, but not in coculture with a methanogenic partner. Thiosulfate, sulfur and cystine are reduced to sulfide. Crotonate is reduced to butyrate. Sulfate, sulfite, fumarate, acetate and nitrate are not reduced. No growth occurs on citrate, 2-oxoglutarate, glutamate, mannose, pectin, lactose, xylose, galactose, maltose, sucrose, rhamnose, raffinose, malonate, lactate, succinate, xylan, dextrin, inulin, melibiose, adonitol, cellobiose, arabinose, polygalacturonate, cellulose, gelatin, butyrate or oleate. The DNA G + C content is $51.5 \mathrm{~mol} \%$. The type strain is $\operatorname{NGA}^{\mathrm{T}}\left(=\mathrm{DSM} 13181^{\mathrm{T}}=\right.$ ATCC BAA-54 $\left.{ }^{\mathrm{T}}\right)$. Iso- lated from the sludge of an anaerobic lagoon treating wool-scouring wastewater from Uruguay.

\section{ACKNOWLEDGEMENTS}

This work was partially supported by PEDECIBA, a Program for the Development of Basic Sciences in Uruguay and Universidad de la República (CSIC).

\section{REFERENCES}

Altschul, S. F., Madden, T. L., Schaffer, A. A., Zhang, J., Zhang, Z., Miller, W. \& Lipman, D. J. (1997). Gapped BLAST and PSI-BLAST: a new generation of protein database search programs. Nucleic Acids Res 25, 3389-3402.

Angelidaki, I., Petersen, S. P. \& Ahring, B. K. (1990). Effects of lipids on thermophilic anaerobic digestion and reduction of lipid inhibition upon addition of bentonite. Appl Microbiol Biotechnol 33, 469-472.

Baena, S., Fardeau, M. L., Labat, M., Ollivier, B., Thomas, P., Garcia, J. L. \& Patel, B. K. C. (1998). Aminobacterium colombiense gen. nov., sp. nov., an amino acid-degrading anaerobe isolated from anaerobic sludge. Anaerobe 4, 241-250.

Etchebehere, C. \& Muxí, L. (2000). Thiosulfate reduction and alanine production in glucose fermentation by members of the genus Coprothermobacter. Antonie Leeuwenhoek 77, 321-327.

Fardeau, M. L., Patel, B. K. C., Magot, M. \& Ollivier, B. (1997). Utilization of serine, leucine, isoleucine, and valine by Thermoanaerobacter brockii in the presence of thiosulfate or Methanobacterium sp. as electron acceptors. Anaerobe 3, 405-410.

Faudon, C., Fardeau, M. L., Heim, J., Patel, B. K. C., Magot, M. \& Ollivier, B. (1995). Peptide and amino acid oxidation in the presence of thiosulfate by members of the genus Thermoanaerobacter. Curr Microbiol 31, 152-157.

Felsenstein, J. (1993). PHYLIP (phylogeny inference package), version 3.5c. Department of Genetics, University of Washington, Seattle, WA, USA.

Fernández, A., Huang, S., Seston, S., Xing, J., Hickey, R., Criddle, C. \& Tiedje, J. (1999). How stable is stable? Function versus community composition. Appl Environ Microbiol 65, 3697-3704.

Girbal, L., Örlygsson, J., Reinders, B. J. \& Gottschal, J. C. (1997). Why does Clostridium acetireducens not use interspecies hydrogen transfer for growth on leucine? Curr Microbiol 35, 155-160.

Hansen, K. H., Angelidaki, I. \& Ahring, B. K. (1998). Anaerobic digestion of swine manure: inhibition by ammonia. Water Res 32, 5-12.

Jeanthon, C., Reysenbach, A. L., L'Haridon, S., Gambacorta, A., Pace, N. R., Glénat, P. \& Prieur, D. (1995). Thermotoga subterranea sp. nov., a new thermophilic bacterium isolated from a continental reservoir. Arch Microbiol 164, 91-97.

McInerney, M. J. (1988). Anaerobic hydrolysis and fermentation of fats and proteins. In Biology of Anaerobic Microorganisms, pp. 373-415. Edited by A. J. B. Zehnder. New York: Wiley.

Mechichi, T., Fardeau, M.-L., Labat, M., Garcia, J.-L., Verhé, F. \& Patel, B. K. C. (2000). Clostridium peptidivorans sp. nov., a peptide-fermenting bacterium from an olive mill wastewater treatment digester. Int J Syst Evol Microbiol 50, 1259-1264.

Menes, R. J., Fernández, A. \& Muxí, L. (2001). Physiological and molecular characterisation of an anaerobic thermophilic oleatedegrading enrichment culture. Anaerobe 7, 17-24.

Mesbah, M., Premachandran, U. \& Whitman, W. B. (1989). Precise 
measurement of the $\mathrm{G}+\mathrm{C}$ content of deoxyribonucleic acid by high-performance liquid chromatography. Int $J$ Syst Bacteriol 39, 159-167.

Örlygsson, J., Krooneman, J., Collins, M. D., Pascual, C. \& Gottschal, J. C. (1996). Clostridium acetireducens sp. nov., a novel amino acid-oxidizing, acetate-reducing anaerobic bacterium. Int J Syst Bacteriol 46, 454-459.

Rand, M. C., Greenberg, A. E. \& Taras, M. J. (1975). Sulfide methylene blue method. In Standard Methods for the Examination of Water and Wastewater, 14th edn, pp. 503-505. Washington, DC: American Public Health Association, American Water Works Association and Water Pollution Control Federation.

Rees, G. N., Patel, B. K. C., Grassia, G. S. \& Sheehy, A. J. (1997). Anaerobaculum thermoterrenum gen. nov., sp. nov., a novel, thermophilic bacterium which ferments citrate. Int $J$ Syst Bacteriol 47, 150-154.

Saitou, N. \& Nei, M. (1987). The neighbor-joining method: a new method for reconstructing phylogenetic trees. Mol Biol Evol 4, 406-425.

Smibert, R. M. \& Krieg, N. R. (1994). Phenotypic characterization, In Methods for General and Molecular Bacteriology, pp. 607-654. Edited by P. Gerhadt, R. G. E. Murray, W. A. Wood \& N. R. Krieg. Washington, DC: American Society for Microbiology.
Stackebrandt, E. \& Liesack, W. (1993). Nucleic acids and classification. In Handbook of New Bacterial Systematics, pp. 152-189. Edited by M. Goodfellow \& A. G. O'Donnell. London: Academic Press.

Stams, A. J. M. (1994). Metabolic interactions between anaerobic bacteria in methanogenic environments. Antonie Leeuwenhoek 66, 271-294.

Thompson, J. D., Higgins, D. G. \& Gibson, T. J. (1994). CLUSTAL $\mathrm{W}$ : improving the sensitivity of progressive multiple sequence alignment through sequence weighting, position-specific gap penalties and weight matrix choice. Nucleic Acids Res 22, 4673-4680.

Touzel, J. P. \& Albagnac, G. (1983). Isolation and characterization of Methanococcus mazeii strain MC3. FEMS Microbiol Lett 16, 241-245.

Van Elsas, J. D. \& Smalla, K. (1995). Extraction of microbial community DNA from soils. In Molecular Microbial Ecology Manual, pp. 1.3.3, 1-8. Edited by A. D. L. Akkermans, J. D. van Elsas \& F. J. de Bruijn. Dordrecht: Kluwer Academic Publishers.

Wayne, L. G., Brenner, D. J., Colwell, R. R. \& 9 other authors (1987). International Committee on Systematic Bacteriology. Report of the ad hoc committee on reconciliation of approaches to bacterial systematics. Int J Syst Bacteriol 37, 463-464. 